\title{
KRITIK SOSIAL DALAM NOVEL GRAFIS SUKAB INTEL MELAYU KARYA SENO GUMIRA AJIDARMA
}

\author{
Muhammad Ardi Kurniawan \\ Universitas Ahmad Dahlan \\ ardi.kurniawan@pbsi.uad.ac.id
}

\begin{abstract}
ABSTRAK
Penelitian ini bermaksud memeriksa kritik sosial dalam novel grafis bertajuk Sukab Intel Melayu. Selain itu, penelitian ini juga hendak melihat relasi teks novel grafis tersebut dengan realitas. Pemeriksaan dilakukan dengan menggunakan teori sosiologi sastra dan kritik sosial. Teori tersebut dipakai dengan mula-mula mencari kemiripan sejumlah data yang ditemukan dalam novel grafis dengan realitas sosial. Kemiripan ini kemudian dilacak lebih lanjut dengan teori kritik sosial. Penelitian ini menggunakan metode deskriptif analitik yaitu dengan menganalisis dan mendeskripsikan data. Sumber data penelitian ini yaitu Sukab Intel Melayu karya Seno Gumira Ajidarma. Data penelitian ini yaitu kutipan novel grafis yang berkaitan dengan kritik sastra. Dengan langkah demikian, hasil penelitian didapatkan sebagai berikut terdapat kemiripan antara teks novel grafis Sukab Intel Melayu dan realitas sosial, khususnya pada masa Orde Baru. Meski demikian, realitas tersebut tidak selalu sama persis. Artinya, ada beberapa distorsi realitas sebagai bagian dari strategi penulis menyembunyikan fakta. Kedua, kritik sosial pada novel grafis ini tertuju pada negara. Secara khusus, sasaran kritik adalah represi dan korupsi yang dilakukan negara pada masa Orde Baru.
\end{abstract}

Kata kunci: novel grafis, kritik sosial

\section{A. PENDAHULUAN}

Novel grafis tersebut ditulis Seno Gumira Ajidarma (selanjutnya disebut SGA) dan digambar Zacky. Arah penelitian ini adalah mengkaji kritik sosial yang terdapat dalam novel grafis tersebut. Berikut berbagai alasan yang menunjukkan mengapa novel grafis tersebut perlu diteliti. Pertama, terdapat bentuk teks baru yang ditulis SGA. Dalam hal ini teks tersebut adalah novel grafis bertajuk Sukab Intel Melayu. Berdasar penelusuran, penelitian terhadap novel grafis tersebut masih terbatas. Padahal, penelitian terhadap teks cerita pendek, naskah drama, atau novel yang ditulis SGA sudah kerap dilakukan. Dengan demikian, penelitian terhadap novel grafis tersebut perlu dilakukan. Selain menambah variasi dan kuantitas penelitian terhadap karya SGA, penelitian ini juga berguna untuk melihat adakah perbedaan atau persamaan novel grafis tersebut dengan teks-teks fiksi SGA yang lain.

Kedua, terdapat kecenderungan kritik sosial dalam teks yang ditulis SGA (Fuller, 2011:105). Hal ini misalnya tampak dalam cerita pendek berjudul Keroncong Pembunuhan 
Lingua Rima: Jurnal Pendidikan Program Studi Bahasa dan Sastra Indonesia

Vol. 8 No. 1 Januari 2019

dan Dilarang Menyanyi di Kamar Mandi.. Dalam Keroncong Pembunuhan, SGA merekam persoalan penembak misterius pada pertengahan 1980-an sekaligus melakukan kritik bahwa persoalan tersebut tidak bisa dilihat dari soal baik dan buruk saja. Sementara dalam Dilarang Menyanyi di Kamar Mandi, SGA melakukan kritik terhadap negara yang melakukan represi terhadap ekspresi seni masyarakat. Dengan kecenderungan demikian, menjadi perlu diperiksa kritik sosial apa yang ditampilkan SGA dalam teks novel grafis yang ditulisnya kali ini.

Ketiga, novel grafis Sukab Intel Melayu terbit tahun 2002. Artinya, buku ini terbit setelah Orde Baru berakhir. Dengan kata lain, buku ini muncul setelah represi negara sudah berkurang. Hal ini membuat novel grafis tersebut perlu dikaji, khususnya berhubungan dengan kritik sosial yang ditampilkannya. Apalagi selama ini, kecenderungan kritik sosial dalam karya SGA ditujukan kepada negara para periode Orde Baru. Hal yang perli diperiksa adalah apakah sasaran kritik SGA dalam novel grafis ini masih negara. Apakah kritik sosial masih ditampilkan dengan menyisipkan realitas pada fiksi.

Keempat, dari pembacaan awal, sejumlah kritik sosial dalam novel grafis tersebut merupakan respon terhadap realitas sosial. Hal ini perlu dilihat lebih jauh. Setidaknya ada tiga hal yang bisa diajukan menjadi pertanyaan untuk melihat lebih jauh, yakni apakah kritik sosial tersebut sekadar rekaman kritik sosial yang muncul di masyarakat, apakah kritik sosial tersebut .respon terhadap realitas sosial, dan bagaimana relasi teks novel grafis tersebut dengan realitas di masyarakat.

Kelima, penelitian terhadap novel grafis masih jarang dilakukan. Seperti ditekankan Kurnia (2012:xi) dan Ajidarma (2011:xvii), penelitian novel grafis di Indonesia masih terbatas. Oleh sebab itu, penelitian terhadap Sukab Intel Melayu perlu dilakukan. Hal ini untuk menambah kuantitas penelitian terhadap novel grafis. Selain itu, penelitian ini dapat dipakai sebagai referensi penelitian lain yang hendak mengkaji objek serupa.

Berdasarkan uraian sebelumnya, dapat diidentifikasi lima masalah sebagai berikut. Pertama, terdapat bentuk teks baru yang ditulis SGA berupa novel grafis. Teks tersebut masih terbatas diteliti. Kedua, terdapat kecenderungan kritik sosial dalam berbagai teks fiksi yang ditulis SGA. Sebagai teks dalam bentuk baru, kritik sosial dalam teks tersebut perlu diperiksa. Ketiga, novel grafis tersebut terbit pada masa represi negara berkurang. Dengan demikian, ada kebebasan dalam mengungkapkan kritik terhadap negara. Karya SGA selama ini banyak berhubungan dengan perkara mengkritik negara. Oleh sebab itu, perlu dilihat sasaran kritik sosial dalam novel grafis yang terbit pasca Orde Baru tersebut. Keempat, pembacaan awal menunjukkan kritik sosial merupakan respon terhadap realitas sosial. Ini perlu dikaji lebih jauh terutama terkait relasi teks fiksi tersebut dengan realitas sosial masyarakat. Kelima, 
penelitian terhadap novel grafis masih terbatas. Oleh sebab itu, perlu dilakukan penelitian untuk menambah kuantitas.

Terdapat dua rumusan masalah yang akan dijawab dalam penelitian ini. Pertama, siapa sasaran kritik sosial dalam novel grafis Sukab Intel Melayu. Kedua, bagaimana relasi kritik sosial dalam novel tersebut dengan realitas yang terjadi di masyarakat. Apakah kritik sosial tersebut sekadar menegaskan kritik sosial yang terjadi di masyarakat atau kritik sosial tersebut merupakan respon terhadap realitas sosial yang terjadi pada saat itu. Kedua rumusan masalah tersebut akan dijawab dengan memakai teori sosiologi sastra dan kritik sosial. Penelitian ini bertujuan untuk membuktikan bahwa teori sosiologi sastra dapat dipakai untuk meneliti novel grafis. Selain itu, penelitian ini juga hendak menunjukkan bahwa novel grafis sebagai medium bercerita yang menggunakan gambar dan tulisan juga bisa dipakai untuk menyampaikan kritik sosial.

\section{B. KAJIAN TEORI}

Terdapat dua teori yang dipakai membantu menjawab rumusan masalah penelitian ini. Dua teori tersebut adalah sosiologi sastra dan kritik sosial. Secara khusus, sosiologi sastra yang dipakai adalah teori sosiologi sastra Alan Swingwood. Pertimbangan yang dipakai adalah kesesuaian teori tersebut dengan rumusan masalah yang hendak melihat relasi teks novel grafis dan realitas sosial. Selain itu, teori kedua yang dipakai adalah teori tentang kritik sosial. Teori ini dipakai untuk melihat kritik sosial seperti apa yang ditampilkan dan ditujukan kepada siapa. Berikut uraian lebih lengkap mengenai dua teori tersebut.

Sosiologi sastra pada dasarnya adalah teori yang melihat teks sastra sebagai refleksi masyarakat, khususunya saat teks tersebut hadir. Refleksi tersebut bisa sekadar cermin yang sama persis. Akan tetapi, pengarang dapat pula mengambil sebagian realitas sosial yang terjadi di masyarakat dengan tujuan tertentu. Untuk memahami lebih detil teori tersebut, berikut akan dipaparkan definisi sosiologi sastra, alasan penggunaan, dan bagaimana teori tersebut dipakai dalam penelitian ini.

Dalam penelitian ini, teori sosiologi sastra yang dipakai adalah teori Alan Swingedood. Secara ringkas, Swingewood (1972:15) membagi sosiologi sastra menjadi tiga perspektif, yakni sastra sebagai dokumen sosial, sastra sebagai refleksi situasi sosial penulis, dan bagaimana penerimaan masyarakat terhadap suatu teks sastra pada periode tertentu. Penelitian ini memakai perspektif pertama yang diajukan Swingewood. Dengan kata lain, penelitian ini memandang teks novel grafis Sukab Intel Melayu sebagai dokumen sosial. Oleh sebab itu, di dalamnya akan dilacak relasi peristiwa atau realitas sosial masyarakat Indonesia dengan teks novel tersebut. Relasi yang dimaksud adalah realitas sosial apa yang tampak dalam novel 
grafis tersebut. Dengan demikian, akan tampak teks novel grafis tersebut merupakan respon atau dokumen sosial suatu masa tertentu atau tidak. Dalam penelitian ini, teks Sukab Intel Melayu diduga merupakan refleksi sejumlah masalah sosial pada masa Orde Baru.

Satu hal yang perlu dicatat adalah refleksi tersebut bukan sekadar cermin belaka. Namun terdapat pula kemungkinan adanya kritik terhadap situasi sosial atau realitas sosial yang dicerminkan. Oleh sebab itu, penelitian ini juga memakai teori kritik sosial untuk melihat kritik sosial apa yang ditampilkan dan siapa sasaran kritik tersebut. Kritik sosial sendiri bukan hal baru dalam kesenian. Dalam Wignjosoebroto dan Suyanto (2006:146) dipaparkan bahwa kritik sosial bisa tampil melalui ideologi, bahasa, rekreasi, seni, dan teror.

Terdapat sejumlah definisi kritik sosial. Menurut Abar (1997:47), kritik sosial adalah bentuk komunikasi dalam masyarakat yang bertujuan sebagai kontrol terhadap suatu sistem sosial. Tindakan yang menyimpang secara sosial dianggap dapat dicegah dengan kritik sosial. Dengan kata lain, kritik sosial berfungsi menjaga suatu sistem sosial tetap berjalan seperti seharusnya. Selain definisi tersebut, Abar juga menawarkan kritik sosial dalam definisi yang berbeda. Dalam definisi yang kedua, kritik sosial berarti sarana komunikasi gagasan baru sembari menilai gagasan lama untuk perubahan sosial. Kritik dalam konteks ini berfungsi membongkar kekuasaan. Dengan kata lain, kritik ini lebih diarahkan kepada penguasa. Tujuan kritik ini adalah perubahan sosial yang terjadi di masyarakat.

Penelitian ini memanfaatkan dua definisi tersebut. Definisi pertama dipakai untuk melihat tindakan menyimpang apa yang dikritik dalam novel grafis ini. Sementara definisi kedua dipakai untuk melihat kepada siapa kritik sosial ditujukan. Dengan demikian, kedua definisi tersebut dapat dipakai untuk membantu menjawab rumusan masalah pertama.

\section{METODE PENELITIAN}

Penelitian ini menggunakan metode deskriptif analitik yaitu dengan menganalisis dan mendeskripsikan data. Sumber data penelitian ini yaitu Sukab Intel Melayu karya Seno Gumira Ajidarma. Data penelitian ini yaitu kutipan novel grafis yang berkaitan dengan kritik sastra. Teknik pengumpulan data dengan metode simak dan catat. Teknik analisis data menggunakan reduksi data, penyajian data dan penarikan simpulan.

\section{HASIL PENELITIAN DAN PEMBAHASAN}

Sukab Intel Melayu berkisah mengenai seorang intel bernama Sukab. Ia diminta atasaannya mencari harta Centini milik mantan presiden Suroto. Pencarian itu dilakukan bersama sejumlah parternya seperti Paidi, Jimbon, Markonah, dan Santinet. Pada proses pencarian tersebut, Sukab menemui berbagai masalah yang menghalanginya menemukan 
harta Centini. Meski bisa mengatasi satu per satu masalah tersebut, pada akhirnya harta Centini tetap tidak diketahui berada di mana.

Telah disebutkan sebelumnya bahwa sosiologi sastra melihat teks sebagai refleksi situasi atau realitas sosial. Akan tetapi, realitas tersebut tidaklah utuh. Ketidakutuhan ini terjadi karena realitas yang hendak ditampilkan sudah mengalami pemotongan. Artinya, realitas tertentu diambil penulis sesuai dengan tujuan penulisan teks tersebut. Penelitian ini, terlacak bahwa realitas sosial yang diambil SGA adalah realitas yang terjadi di Indonesia, khususnya pada masa Orde Baru. Hal ini terlacak dari sejumlah gambar dan teks yang terdapat dalam novel grafis tersebut. Dari dua gambar berikut misalnya, dapat terlihat Indonesia menjadi latar cerita.

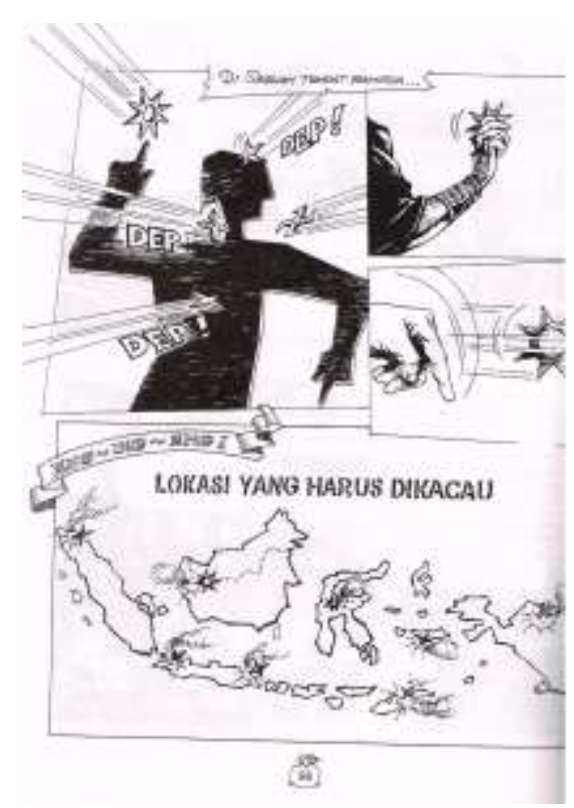

Secara spesifik, realitas yang diambil adalah kasus korupsi yang dilakukan mantan presiden Soeharto. Realitas ini terlacak setelah sejumlah data yang menunjukkan kesejajaran itu dikumpulkan menjadi satu, dikategorikan dan disejajarkan dengan sejumlah fakta mengenai Orde Baru. Fakta tersebut diambil dari dokumen, artikel jurnal, dan media massa. Setelah proses tersebut dilakukan, dapat terlihat sejumlah realitas yang ditampilkan SGA dalam Sukab Intel Melayu. Meski demikian, tidak semua realitas ditampilkan sama persis. Sejumlah realitas tersebut didistorsi melalui berbagai cara. Apabila melihat rekam jejak penulisan SGA, hal demikian bukan hal baru. Ia beberapa kali menyembunyikan fakta dalam sejumlah karya fiksinya. Hal ini untuk menghindari sensor negara terhadap teks sastra. Untuk melihat bagaimana distorsi tersebut dilakukan dalam teks novel grafis Sukab Intel Melayu, berikut disajikan sejumlah bukti. 
Lingua Rima: Jurnal Pendidikan Program Studi Bahasa dan Sastra Indonesia Vol. 8 No. 1 Januari 2019

\section{a) Harta Centini}

Harta Centini teracu kepada harta yang dimiliki mantan presiden Soeharto, keluarga, dan rekan bisnisnya. Pada intinya harta tersebut merupakan hasil praktik kolusi, korupsi dan nepotisme (Tempo, 2008:5). Dalam salah satu gambar dalam komik yang akan ditampilkan berikut, tampak tulisan "Daftar Upeti", "Daftar Pemerasan", "Daftar Sogokan", dan "Daftar Tilep" yang secara tidak langsung hendak menunjukkan bagaimana harta tersebut diperoleh. Meski dapat teracu demikian, SGA tidak secara langsung menunjukkan harta tersebut milik Soeharto. Ia mendistorsi lewat penggunaan nama "Harta Centini" yang dapat dikatakan diambil dari "Harta Cendana". Cendana merupakan sebuah istilah untuk menyebut keluarga Soeharto.

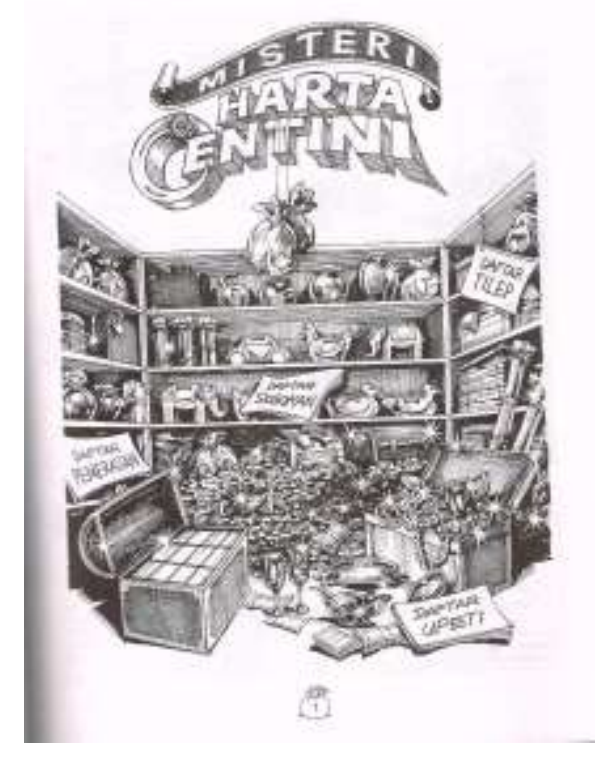

\section{b) Soeharto sebagai Suroto}

Selain distorsi nama harta yang akan dicari. Nama mantan presiden Soeharto juga didistorsi dengan nama Suroto. Artinya, meski didistorsi, perubahan nama tersebut tidak terlalu jauh berbeda dengan aslinya. Acuan Suroto sebagai Soeharto sendiri mudah ditemukan lewat sampul majalah TIME yang digubah dalam novel grafis tersebut dengan nyaris sama persis. 

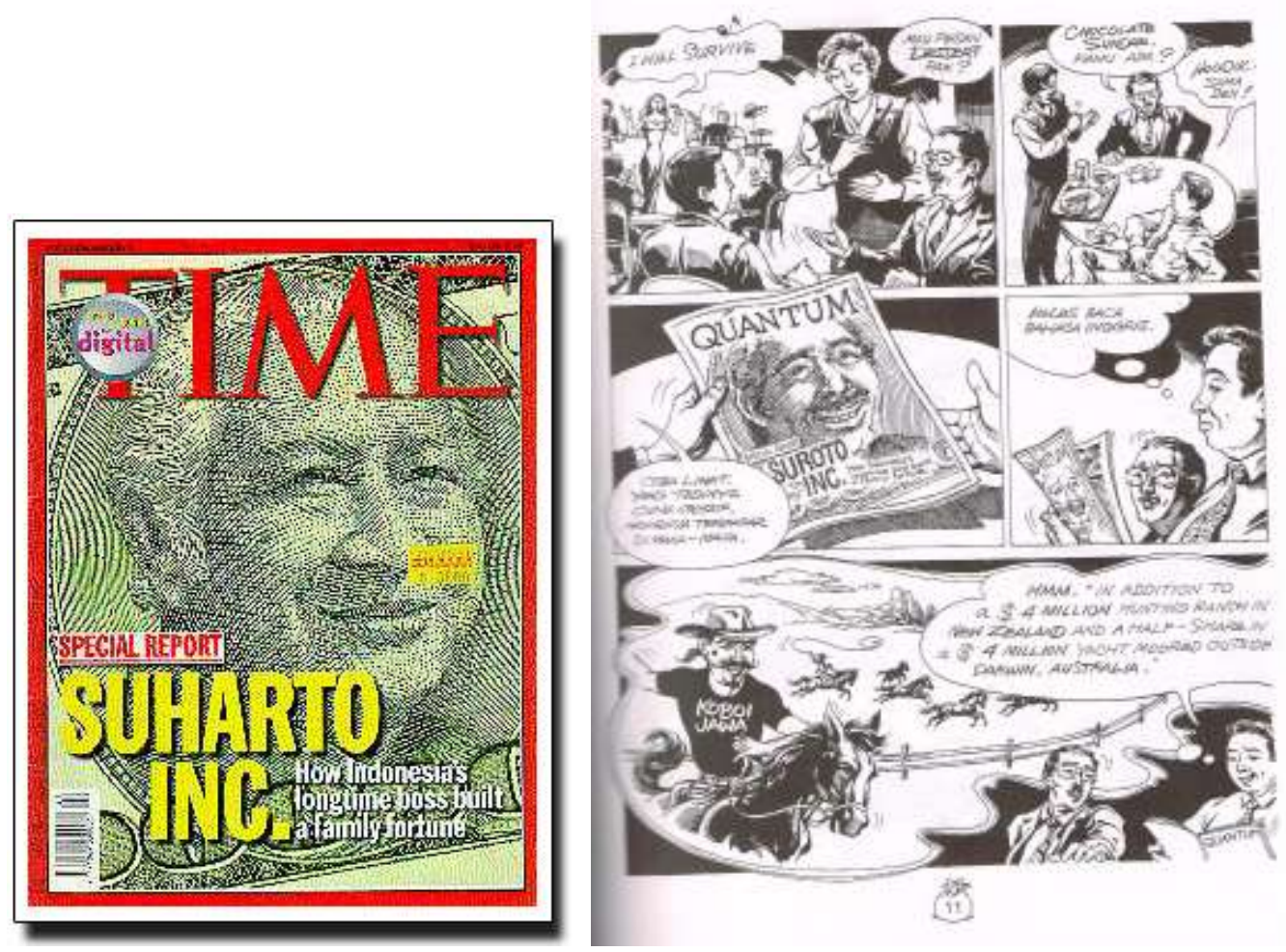

\section{c) Korupsi 30 Tahun}

Dalam salah satu panel komik, terlihat salah satu tokoh berujar mengenai korupsi 30 tahun. Hal ini mudah diterka memiliki kesejajaran dengan kasus korupsi pada masa Orde Baru yang berjalan 32 tahun (Hadi dan Kasuma, 2012:1). Dengan kata lain, tidak ada distorsi yang berarti dalam pencantuman persoalan korupsi ini. Pembaca yang memahami konteks sosial Orde Baru akan dengan mudah menangkap bahwa korupsi 30 tahun yang dimaksud adalah korupsi pada masa Orde Baru. 


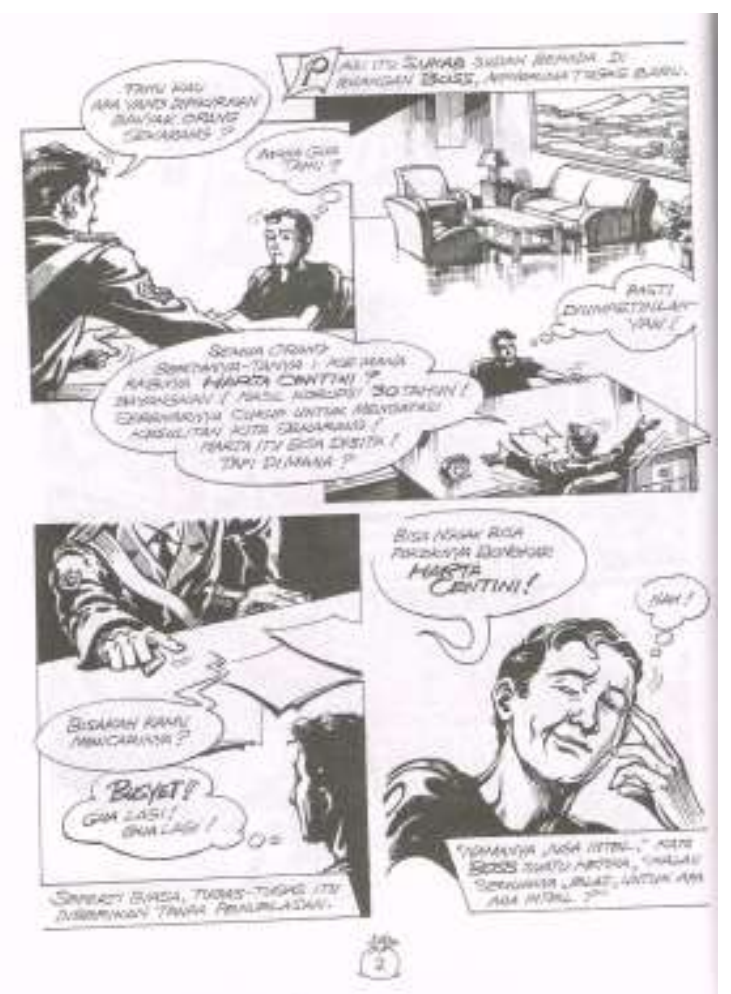

Dari sejumlah data yang dipaparkan pada bagian sebelumnya, dapat dilihat bahwa sasaran kritik sosial dalam Sukab Intel Melayu adalah negara, khususnya pada masa Orde Baru. Fokus utama kritik memang pada persoalan korupsi yang dilakukan dengan memanfaatkan kekuasaan terhadap negara. Artinya, novel grafis yang terbit pasca Orde Baru ini hendak menjadi pengingat publik bahwa persoalan hukum terhadap kasus korupsi belum selesai. Penyelesaian tersebut makin rumit karena dapat dikatakan Orde Baru tidak sepenuhnya berakhir. Secara periodik, nama Orde Baru memang sudah tidak ada. Akan tetapi, sejumlah persoalan warisan Orde Baru tidak dengan mudah diatasi.

Selain persoalan korupsi, terdapat persoalan lain yang mendapat kritik sosial dalam novel grafis ini. Persoalan tersebut adalah represi. Apabila dilacak, represi memang bukan hal yang baru pada masa Orde Baru. Represi pada masa tersebut, dengan atau tidak disertai kekerasan, kerap dipakai untuk membungkam mereka yang memiliki pendapat atau suara berbeda dengan negara. Lebih jauh lagi, represi dipakai sebagai alat untuk mempertahankan kekuasaan. Dalam novel grafis ini, represi tersebut ditunjukkan lewat jalur kekerasan. Hal ini ditunjukkan lewat usaha penguasa yang berusaha mematikan orang-orang yang hendak membongkar misteri harta Centini. Usaha tersebut tampak dalam panel berikut. 


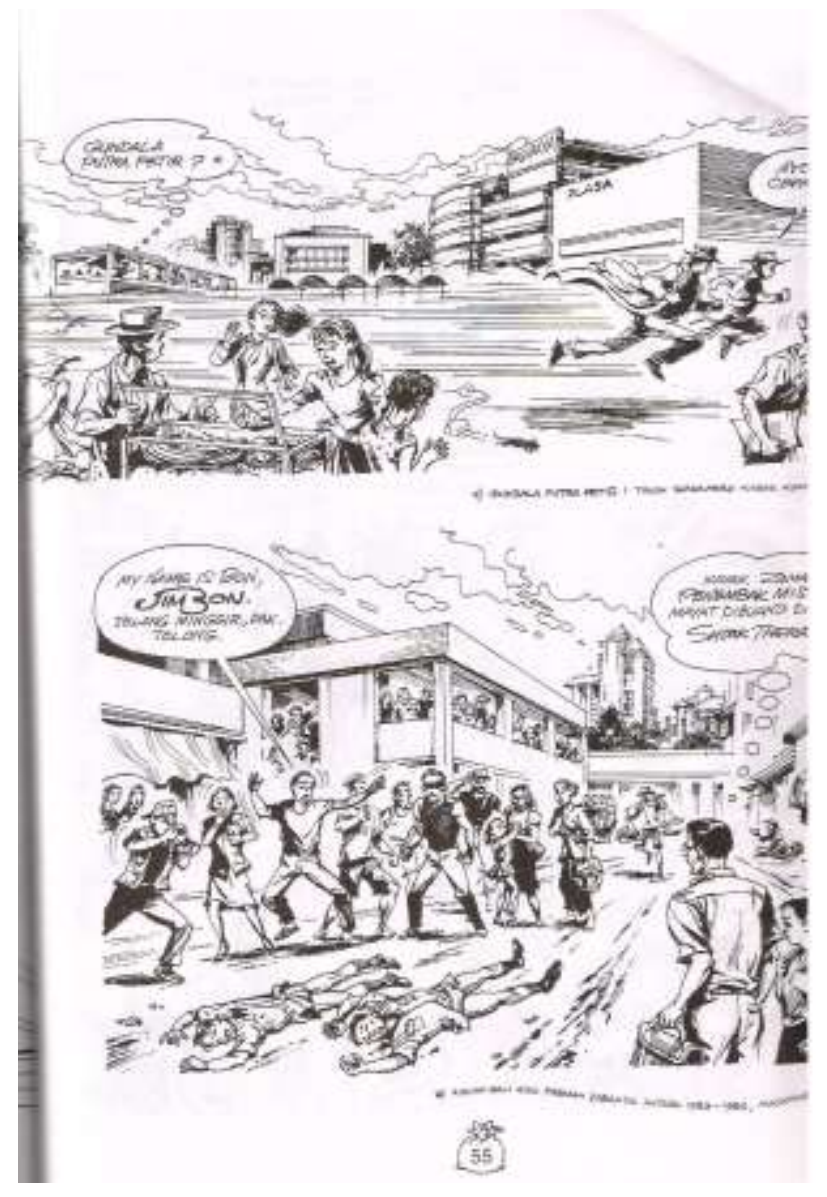

Secara khusus, novel ini memanfaatkan salah satu persoalan kekerasan yang cukup serius terjadi pada masa Orde Baru, yakni 'penembak misterius' (Tempo, 2008:78). Meski harus dicatat pula, sejumlah kasus kekerasan lain juga dilakukan negara pada saat itu. Agaknya, pemilihan kasus 'penembak misterius' ini selain disesuaikan dengan kebutuhan cerita novel grafis, juga dipilih karena merupakan kasus yang cukup mendapat perhatian publik. Hal ini apabila dilacak lagi sebenarnya bukan hal yang baru dalam rekam jejak kepengarangan SGA. Ia pernah menulis cerpen dengan latar peristiwa tersebut dalam Keroncong Pembunuhan.

Apabila dilihat lebih luas pula, kritik sosial yang ditampilkan dalam novel grafis ini sebenarnya adalah repetisi dari apa yang kerap dilakukan SGA dalam cerpan atau novelnya. Ia fokus mengkritik persoalan represi yang dilakukan negara. Hanya saja, kali ini, ia memanfaatkan medium baru untuk bercerita, yakni novel grafis. Pemilihan medium ini, untuk sementara, dapat diduga adalah usaha SGA untuk menyampaikan kritik sosial lewat medium yang lebih popular dibanding cerpen dan novel yang kerap kali terkesan sebagai bacaan serius. 
Lingua Rima: Jurnal Pendidikan Program Studi Bahasa dan Sastra Indonesia

Vol. 8 No. 1 Januari 2019

\section{SIMPULAN DAN SARAN}

Novel grafis Sukab Intel Melayu merekam sejumlah realitas sosial untuk dipakai dengan tujuan tertentu. Dalam hal ini, realitas sosial yang direkam adalah persoalan korupsi pada masa Orde Baru. Realitas tersebut dipakai sebagai ruang untuk melempar kritik sosial, terutama pada persoalan korupsi dan represi yang dilakukan negara pada saat itu. Dengan demikian, dapat dibuktikan bahwa dalam novel grafis yang ditulis SGA tersebut terdapat kritik sosial.

\section{E. DAFTAR PUSTAKA}

Abar, Akhmad Zaini. 1997, "Kritik Sosial, Pers dan Politik Indonesia", dalam

Mohammad Mahfud MD (ed.). Kritik Sosial dalam Wacana Pembangunan. Yogyakarta: UII Press.

Ajidarma, Seno Gumira dan Zacky. 2002. Sukab Intel Melayu. Jakarta: KPG.

_. 2011. Panji Tengkorak: Kebudayaan dalam Perbincangan. Jakarta: KPG.

Fuller, Andy. 2011. Sastra dan Politik. Yogyakarta: Insist.

Kurnia, Lilawati. 2016. Kota Urban Jakarta dalam Komik karya Zaldy. Jakarta: Obor.

Swingewood, Alan dan Diana Laurenson. 1972. The Sociology of Literature. London: Granada Publishing Limited.

Tim Penyusun. 2008. "Edisi Khusus Soeharto, Setelah Dia Pergi”. Tempo, 4 - 10 Februari 2008.

Wahyono Hadi, Dwi dan Gayung Kasuma. 2012. "Propaganda Orde Baru 1966-1980" dalam Jurnal Verleden Vol. 1, No.1 Desember 2012.

Wignjosoebroto, Soetandyo dan Bagong Suyanto. 2006. "Pengendalian atau Kontrol Sosial" dalam Bagong Suyanto (ed.). Sosiologi:Teks Pengantar dan Terapan. Jakarta: Prenada. 